\title{
THE VALUE PUMP: INTRODUCING A THERMODYNAMIC MODEL TO ASSESS INNOVATION SYSTEMS' PERFORMANCE
}

\author{
IGONE PORTO GOMEZ \\ Departamento de Economía, UNIVERSIDAD DE DEUSTO, DEUSTO BUSINESS SCHOOL, ESPAÑA \\ E-mail: igone.porto@deusto.es \\ JON MIKEL ZABALA ITURRIAGAGOITIA \\ Departamento de Economía, UNIVERSIDAD DE DEUSTO, DEUSTO BUSINESS SCHOOL, ESPAÑA \\ FERNANDO CORTÉS MARTÍNEZ \\ Departamento de Mecánica, Diseño y Organización Industrial, UNIVERSIDAD DE DEUSTO, Facultad de \\ Ingeniería, ESPAÑA \\ CRISTINA GUTIERREZ-CAÑAS MATEO \\ Departamento de Química, UNIVERSIDAD DEL PAIS VASCO, ESCUELA TÉCNICA SUPERIOR DE \\ INGENIERÍA, ESPAÑA
}

\section{La Bomba de Valor: Introducción de un modelo termodinámico para la evaluación de los Sistemas de Innovación}

\begin{abstract}
Econophysics and thermodynamics have not tackled the measurement of innovation performance as to yet. This paper introduces a thermodynamic approach based on heat pump models, and which is applied to assess the performance of innovation systems. This thermodynamic model can be used to assess innovation performance in such levels as the national, regional, sectoral as well as firm related contexts. This model is applied in the case of the United States of Mexico. In particular we focus on the regional dimension, by measuring innovation performance of Mexican regions between 2010 and 2013. Our results reveal that the conclusions achieved with the application of this approach to measuring innovation performance are robust and stable over time.
\end{abstract}

Keywords: thermoeconomics, heat pump, innovation system, performance.

\section{RESUMEN}

La medición del desempeño innovador de la innovación no ha sido aún abordada desde la perspectiva de la econofísica y la termodinámica. El artículo desarrolla un marco termodinámico, basado en modelos de bomba de calor, que se emplea para evaluar el desempeño de los sistemas de innovación. Este modelo se puede utilizar para evaluar el desempeño tanto a nivel nacional, como regional, sectorial y empresarial. El marco desarrollado se aplica en el caso de los Estados Unidos de México, midiendo el desempeño de la innovación de las regiones mexicanas entre 2010 y 2013. Nuestros resultados revelan que las conclusiones alcanzadas con la aplicación de este enfoque para medir el desempeño innovador son sólidas y estables en el tiempo.

Palabras clave: termodinámica, máquina de calor, sistema de innovación, desempeño.

JEL codes: L25, M21, O32, O33, O47.

Artículo recibido el 9 de febrero de 2019 y aceptado el 22 de mayo de 2019 Artículo disponible en versión electrónica en la página www.revista-eea.net ISSN 1697-5731 (online) - ISSN 1133-3197 (print) 


\section{INTRODUCTION}

Thermoeconomics (Tribus and Evans, 1962; Georgescu-Roegen, 1976) is a branch of thermodynamics that tries to explain economics through general physics laws, in particular, of energy and mechanics (Bali, 2011; Cleveland, 2006). While initially thermoeconomics was just related to the improvement of the 'cost' of thermodynamic processes a new trend has emerged pointing at the generation of physics based models and their application into economics. Thermodynamic models are thus used to evaluate economic performance through the perception and consideration of statistical physic approaches, in what is commonly referred to in the literature as 'econophysics' (Saslow, 1999; McCauley, 2006; Rosser, 2008).

Examples of the use of econophysic models can be found principally in finance (Plerou et al., 2003; Rickles, 2008) and macroeconomics (Richards, 2000), and more recently new research paths have also been proposed for econometricians (Zapart, 2015). A quick review of the application of thermoeconomic approaches reveals how the vast majority of contributions can be found on the cost analysis of the processes taking place inside firms. However, this trend is slowly changing.

While research fields like traffic (Weber et al., 2007) or geography (Pelorosso et al., 2017) have explored the potential of thermodynamic models, the field of innovation studies shows an almost outright absence of such consideration (for an exception see Grupp, 1990). The few original works that can be found in this regard resort to entropy related measures to assess the quantity and quality of the relationships taking place within an innovation system (Haiping, 2013; Abbassi et al., 2014; He and Liu, 2015). In these studies entropy is used as a measure of the efficiency of innovation activities. However, the field of innovation still lacks a complete thermoeconomic model that could be used in different levels and contexts. From our point of view, a fully-fledged thermodynamic model could be useful to compare innovation performance in such levels as the national, regional, sectoral as well as firm related contexts, among others. Such a model could for example rest on a full understanding of the first and second thermodynamics principles and their application in these contexts and levels. Summing up, it can be asserted that econophysics and thermodynamics have not thoroughly tackled the measurement of innovation performance as to yet. This paper provides a preliminary step in this direction by introducing a thermodynamic approach that is applied to assess the efficiency of innovation systems.

Innovation is a key component of the economy and has for long become crucial to boost the competitiveness of firms and territories. Innovation plays a central role in firms' and territories' relative competitive advantage, and in long term economic growth (Howitt and Aghion, 1998). From an economic geography point of view, considering the co-location of partners in the same territory is central to elucidate innovation (Narula and Santangelo, 2009). In this regard, the literature on innovation studies has discussed at length how the innovation performance achieved by a system as a whole is to a great extent determined by its interactive character, which is in turn dependent on the relationships among the actors involved in the generation of innovations and the processes that translate innovation into economic growth (i.e., firms, universities, research institutions, financial systems, governments, etc.).

The aim of this article is to introduce a new approach to assess innovation performance based on thermal machine principles (i.e., heat pump). This novel approach is applied in the case of the United States of Mexico. In particular we focus on the regional dimension, by measuring innovation performance of Mexican regions through the application of such an approach. The data are gathered from the ESIDET survey (Encuesta Sobre Investigación y Desarrollo Tecnológico - Survey on Research and Technological Development) which measures the performance of Mexican firms in terms of their research and innovation activities. One of the particularities of this dataset, and which justifies its use in this paper, is that it monetizes the activities carried out in the development of innovation (Santiago et al., 2017). This implies that innovation support activities are measured in monetary terms (i.e., in pesos), rather than in dichotomic terms (i.e., yes-no type of questions) or through the use of discrete variables, as done by most research and development and innovation surveys worldwide. The thermodynamic model introduced in the paper calls for the measurement of the variables used in it in monetary terms, that is why the ESIDET database from Mexico constitutes one of the few cases to be used for such a purpose.

The remainder of this paper is organized as follows. Section 2 provides an overview of the literature on the assessment of regional innovation performance. Section 3 begins with an illustration of the 
thermodynamic model developed in the paper. It then presents the main features of Mexico as a case study in which such model is applied. Section 4 provides evidence of the results achieved at the level of Mexican regions. Finally, Section 5 deliberates around the main outcomes of this novel approach while discussing its main limitations and providing new perspectives for future research.

\section{LITERATURE REVIEW}

This section provides a review of the literature as regards the two key topics underlying the paper, namely, regional innovation performance, and the application of thermodynamic approaches to characterize innovation systems. As to the former, the section will not only focus on the variables under use to assess innovation performance, but also on the methods under use. In turn, the latter will initially discuss the thermodynamic models that have been employed in the field of applied economics, and specifically in the field of innovation studies, to then focus on the few contributions that are found as to date regarding the application of thermodynamic models (mainly based on entropy measures) to assess innovation systems' performance.

\subsection{Innovation performance}

Globalization is promoting a context in which not only cross-country differences emerge, but also where intra-regional asymmetries arise. In order to reduce the gap and boost economically damaged regions greater efforts have been made not only from the political perspective (for example, through the development of Smart Specialization Strategies - see European Commission, 2011, 2012) but also from the academic side, to help assess overall economic performance, and hence, provide evidence for policy making. Innovation is undoubtedly one of the key determinants (if not the most central one) of economic development and growth (Freeman, 2002; Verspagen, 2005). Henceforward, in this review we will focus on the literature that has tackled the measurement of innovation performance.

Innovation is recognized as a social and interactive process (Lundvall, 1992), where the development of innovations takes place as a result of cooperative and collaborative relationships among a large variety of stakeholders. Similar to the classical explanation of quantum physics, epitomized by Schrödinger's cat, which could be in two states at the same time, innovation can also be characterized as both a process and a result. In this context, a literature known as innovation studies emerged in the 1990s (Fagerberg et al., 2012; Martin, 2012), which underlines the systemic connection between knowledge producers (i.e., universities, research centers, etc.), knowledge consumers involved in productive activities (i.e., firms), and institutional actors such as development agencies, governments, councils, etc. Initially, the original perspective adopted in this stream of literature was the national one (Nelson, 1993; Edquist, 1997). However, further contributions were outlined in the following years, highlighting other perspectives such as the regional (Cooke et al., 1997; Braczyk et al., 1998), sectoral (Malerba, 2002) and technological (Carlsson and Jacobsson, 1994), to mention a few.

The main purpose of an innovation system is to create the conditions for the generation, emergence and diffusion of innovations (Metcalfe, 1995; Edquist, 2011). As discussed at length by Leydesdorff (2001), and more recently conceptualized by Borras and Edquist (2019), the performance of any type of system should be analyzed from a holistic perspective, examining its performance and evolution as a whole, rather than setting the view on particular measures or key indicators. However, probably due to the lack of data (Audretsch and Feldman, 1996; Evangelista et al., 2001), most contributions focus on particular features of innovation systems, notwithstanding they very often acknowledge that they do not provide an integrative and exhaustive assessment of the system as a whole. Most studies rely on the data gathered by innovation surveys, such as the Community Innovation Survey, or Innovation Scoreboards, in spite of the potential flaws and biases that may result from these (Doloreux and Porto-Gomez, 2017; Edquist et al., 2018).

When the data provided by innovation surveys and scoreboards are examined in detail several problems arise, which makes cross-country benchmarking analyses partial and loose (see ZabalaIturriagagoitia et al., 2007b). Among the many potential explanations, the heterogeneity of territories (particularly at the regional level), the multidimensionality of innovation systems, and differences in the criteria applied by national and regional statistical offices are worth being highlighted. Innovation systems are usually defined as territorial innovation models (Moulaert and Sekia, 2003) made of three 
interrelated subsystems (Autio, 1998; Porto-Gómez et al., 2016): knowledge exploration, knowledge exploitation and institutional or policy subsystems. The extant evidence on the measurement of innovation has traditionally focused on manufacturing industries in the knowledge exploitation (or productive) subsystem, and in the performance of research infrastructures located in the knowledge exploration subsystem. The institutional subsystem has so far remained absent in most contributions, mainly due to the difficulties in defining variables that can help characterize this policy subsystem.

Most of the indicators being used, despite they vary from case to case, rely on the variables considered by the Oslo Manual (OECD/Eurostat, 2018). These embrace R\&D expenditures, in both the public and private sectors, the number of innovative firms (or their share as compared to the total number of firms), patent applications (or granted patents), and the number of innovations introduced in the marketplace (product and process innovations), despite new indicators are continuously being suggested in the literature.

As a consequence of the limitations provided by the availability of data, innovation systems are frequently seen as input-output systems (Zabala-Iturriagagoitia et al., 2007a). From this point of view, innovation systems are commonly interpreted from a rationale of "the more the better" - the more resources invested in it (i.e., inputs), the better the performance of the system (i.e., outputs). However, as Edquist et al. (2018) discuss at length, this simple understanding of innovation systems' performance may provide a biased picture.

How does one then capture the true performance of an innovation system? What type of analytical approach could be adopted when assessing the performance of innovation systems? Which indicators could be considered? These complex questions have been extensively tackled in the literature, despite the answers as to date remain being rather partial. 20 years ago, Nauwelaers and Reid (1995) made a deep review of the approaches used in the assessment of innovation systems, based on input-output analyses. They were particularly interested in quantitative indicators, mainly facing technology creation and its diffusion, as well as analyzing territorial heterogeneity. In recent years, the literature has called for the consideration of efficiency analyses for measuring innovation performance (Nasierowski and Arcelus, 2012; Carayannis and Grigoroudis, 2014). The main advantage of this approach is that it helps assess how the resources being devoted to the system are being used and translated into outputs (Edquist et al., 2018). Hence, they provide insights on the functions developed within the system as a whole (i.e., how the system works) rather than how much is invested and achieved in it.

The literature on efficiency measurement relies on two main methodologies:

- Non-parametric techniques, such as Data Envelopment Analysis: this methodology resorts to input-output variables (see Charnes et al., 1978). In it, efficiency is measured as the distance of every decision making unit to a best practice frontier which is composed by those observations that show the best performance, as they are able to produce the largest amount of outputs for a given set of inputs. Some of the scholars that have used these methods for measuring the performance of (national and regional) innovation systems include ZabalaIturriagagoitia et al. (2007a), Chen and Guan (2012), Nasierowski and Arcelus (2012) and Carayannis and Grigoroudis (2014) to name a few.

- Tripe Helix Binary Entropy: based on information entropy, this methodology measures the average rate at which University-Government-Industry relations are produced stochastically. The main proponents of this approach are Etzkowitz and Leydesdorff (1995). It has been widely used to assess innovation systems ' performance, mainly at the national level, in such countries as the USA, Russia, China or Spain (Cai and Lu, 2014; Ivanova and Leydesdorff, 2014; Leydesdorff and Porto-Gómez, 2019).

\subsection{Thermodynamics of innovation systems}

Beyond the previous binary entropy, we can also find other studies that have resorted to traditional mechanic or physical entropy, despite they are not mainstream. Pati (2009) for example attempted to define if the human resources in R\&D and innovation activities could also be modelled following entropy and enthalpy models. Specifically, this author used two physics variables to model this behavior. First he considered Pressure as an input variable, which was defined as the pressure of the involvement 
of top managers, and then Volume was defined as the output variable that helped measure the innovation goals to be achieved.

Haiping (2013) and He and Liu (2015) were among the first who approached innovation systems from a thermodynamic perspective, despite their preliminary contribution did not provide a conceptual definition of entropy in the context of innovation systems. In this regard Haiping (2013: 647) discussed that if the entropy of the system "is increasing or positive, it shows that the system is in a mess, the system performance will down and gradually decline, which is a result of a disorder interaction between the main elements of inner system, but if the system continuously introduces energy from outside and material to offset system of internal interaction disorder, then the internal system's positive entropy decreases and negative one increases, the system enters order and form the dissipative structure". The main problem of this proposal is that the measurement of the variation of a systems' entropy would require determining the entropy variation of each of the individual process in each of the subsystems of an innovation system, something that is certainly not feasible as to date due to the limitations provided by the data when characterizing the three subsystems discussed above (i.e., knowledge exploration, knowledge exploitation, institutional subsystem).

Although the studies provided by these authors suggest a long list of variables that could measure economic, social and technical entropy based on input variables (e.g., number of high schools, research institutions, high tech firms, subsidies received for R\&D), as indicated in Table 1, below, they do not measure each of the process that could be considered. In other words, they proposed aggregate entropy measures to assess innovation systems entropy as a whole, but do not evaluate the entropy of individual process.

Finally, it is also necessary to underline the conceptual work by Gomez-Uranga and Etxebarria (2015), who are to the best of our knowledge the first who provide a conceptual approach for the development of a thermodynamic model to be applied in the context of innovation systems. While they also recognize the main problems derived from the lack of data, they offer a list of variables that could potentially be considered when measuring the behavior of a system.

\section{METHODOLOGY}

\subsection{The heat pump approach}

Thermal machines are engineering devices whose function is to transform heat in work, or vice versa, using the difference of temperature between a hot focus of temperature $\mathrm{TH}$ a cold focus with a lower temperature $\mathrm{TH}$. This energy transformation is carried out by means of different individual processes given on the fluid inside the machine, exchanging energy with the surrounding environment in the form of work and heat. Thermal machines are governed by the fundamental principles of thermodynamics. The first principle, known as the energy conservation principle, states that in steady state the resultant output energy must be equal to the resultant input energy,

$$
Q_{\mathrm{H}}=Q_{\mathrm{L}}+W_{\text {net }}
$$

where $\mathrm{QH}$ and QL represent the heat related to the hot and cold focal points, respectively, and Wnet is the net work related to the machine, which may be generated or consumed. In this regard, it is possible to classify thermal machines into the following typologies:

- Generating work machines, such as internal combustion engines, gas turbines, or steam turbines. These machines take a share of the heat $\mathrm{Q}_{\mathrm{H}}$ incoming from the hot focus to generate work Wnet, expelling the remaining heat $\mathrm{Q}_{L}$ to the environment (see Figure 1.a).

- Consuming work machines, as air conditioning or refrigerating machines whose objective is to cool a closed space, or heat pumps that heat a certain space. These machines extract energy $\mathrm{Q}_{\mathrm{L}}$ to expel a total energy $\mathrm{Q}_{\mathrm{H}}$ by means the consumption of certain amount of work Wnet (see Figure 1.b). 
Table 1.

Variables under consideration for the China RIS entropy evaluation.

\begin{tabular}{|c|c|c|}
\hline \multirow{8}{*}{$\begin{array}{c}\text { Total Entropy } \\
\text { Value } \\
\text { Parameter }\end{array}$} & \multirow{3}{*}{$\begin{array}{l}\text { Structure } \\
\text { Entropy A1 }\end{array}$} & Quantity of Higher School B11 \\
\hline & & Quantity of Research Institutions B12 \\
\hline & & Quantity of High-tech Enterprises B13 \\
\hline & \multirow{5}{*}{$\begin{array}{l}\text { Input } \\
\text { Entropy A2 }\end{array}$} & Funds of R\&D (Hundred Million Yuan) B21 \\
\hline & & Proportion of The Funds of R\&D in GDP B22 \\
\hline & & $\begin{array}{l}\text { Expenditure of The Funds of R\&D in Large and } \\
\text { Medium-sized Enterprises (Hundred Million Yuan) B23 }\end{array}$ \\
\hline & & $\begin{array}{l}\text { Proportion of Government of Science and Technology } \\
\text { Funding in Financial Expenditure B24 }\end{array}$ \\
\hline & & Totality of Technician (Ten Thousand) B25 \\
\hline \multirow{12}{*}{$\begin{array}{c}\text { Form of } \\
\text { Regional } \\
\text { Innovation } \\
\text { Performance, } x 1\end{array}$} & \multirow{3}{*}{$\begin{array}{c}\text { Technical } \\
\text { Benefit } \\
\text { Entropy A3 }\end{array}$} & Number of Patent Application B31 \\
\hline & & Number of Patent for Authorization B32 \\
\hline & & $\begin{array}{l}\text { Number of Scientific and Technological Achievements } \\
\text { B33 }\end{array}$ \\
\hline & \multirow{5}{*}{$\begin{array}{c}\text { Technical } \\
\text { Benefit } \\
\text { Entropy A3 } \\
\text { Economic } \\
\text { Benefit } \\
\text { Entropy A4 }\end{array}$} & $\begin{array}{l}\text { Number of Published Scientific Papers (Ten Thousand) } \\
\text { B34 }\end{array}$ \\
\hline & & $\begin{array}{l}\text { Volume of Transaction in Technology Market (Hundred } \\
\text { Million Yuan) B35 }\end{array}$ \\
\hline & & $\begin{array}{l}\text { Volume of Export of High-tech Products (Hundred } \\
\text { Million Yuan) B41 }\end{array}$ \\
\hline & & Regional Per Capita GDP (Ten Thousand) B42 \\
\hline & & Growth Rate of Regional GDP B43 \\
\hline & \multirow{4}{*}{$\begin{array}{c}\text { Social } \\
\text { Benefit } \\
\text { Entropy A5 }\end{array}$} & Control Rates of Industrial Waste Water Discharge B51 \\
\hline & & $\begin{array}{l}\text { Rate of Multipurpose Utilization of Industrial Solid } \\
\text { Wastes B52 }\end{array}$ \\
\hline & & Social employment (Ten Thousand) B53 \\
\hline & & $\begin{array}{l}\text { Droop Rate of Energy Consumption Per Unit Product } \\
\text { (\%) B54 }\end{array}$ \\
\hline
\end{tabular}

The second principle of thermodynamics is related to the quality of energy. This principle states that, unlike other types of energy, heat is not completely convertible into mechanical energy. In effect, as the thermal machine operates according to the different processes followed by the fluid, the energy degrades, and this degraded energy will not be usable in the form of mechanical work. Energy can thus be divided into exergy and anergy, which are the usable part that can be converted into mechanical work and the degraded part, respectively. The amount of degraded energy (or destroyed exergy) is determined through the concept of entropy. By quantifying how much entropy is generated in each of the processes that occur inside the thermal machine one can determine the destroyed exergy, that is, the loss of ability of the thermal machine to perform mechanical work.

Figure 1.-

Schematic representation of thermal machines: a) a thermal engine that converts heat into work; b) a heat pump that transforms work into heat.

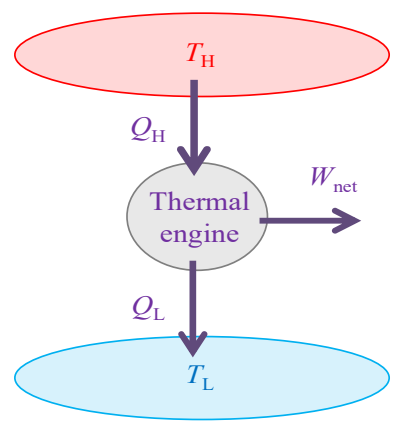

(a)

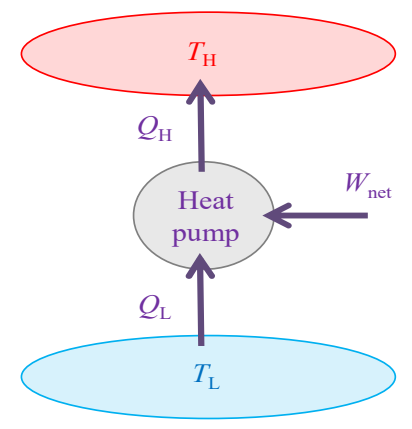

(b)

Source: own elaboration. 
From a global point of view, and alternatively to the use of the concept of entropy, the efficiency $\eta$ of a thermal engine can be defined as the ratio between the work done and the available energy,

$$
\eta=\frac{W_{\text {net }}}{Q_{\mathrm{H}}}
$$

so that the efficiency $\eta$ will always be smaller than one (i.e., $<100 \%$ efficiency). Regarding the heat pump, the second principle states that it is not possible to transfer energy from a cold spot to a hotter one without the consumption of external work $\mathrm{W}_{\text {net. }}$ As a result, the Coefficient of Performance (COP) is defined as

$$
C O P=\frac{W_{\text {net }}}{Q_{\mathrm{H}}}
$$

so that the COP becomes larger when the amount of consumed work $\mathrm{W}_{\text {net }}$ is smaller.

In this paper we consider that the performance of innovation systems can be assessed in a similar way to that of thermal machines. From this point of view, 'innovation machines', or in the words of Schumpeter (1934) innovation as the dynamic "deus ex machina" of capitalism, transfer (economic) resources between a cold focus with low innovative capacity and low competitiveness, and a more innovative and competitive hot spot by means of the investments made in the system by the large variety of stakeholders embedded in it, such as private companies or public institutions. By analogy with thermal machines, it becomes clear that comparing innovation systems with the refrigerating machine model is not a reasonable choice to do, because they seek to cool a cold spot (i.e., decrease the innovation performance of a system that already has low innovativeness). Similarly, a model based on thermal engines would not suit our context either, since the purpose of firms and territories when developing innovation activities is to obtain returns on investments and obtain a benefit.

We propose here to assess the performance of innovation systems based on a heat pump model, or "value pump" model. We consider the heat pump model is the one that suits best with the context of innovation systems, as it requires an external amount of work $\mathrm{W}_{\text {net }}$ (e.g., through investments in R\&D) to transform the (economic) resources available in the cold spot $\mathrm{Q}_{\mathrm{L}}$ into added value in the hot spot $\mathrm{Q}_{\mathrm{H}}$. Thus, the performance of the innovation machine as a value pump can be evaluated through the $C O P$ as defined in (3). The challenge lies in adequately identifying the value created $\mathrm{Q}_{\mathrm{H}}$ and the external work made $\mathrm{W}_{\text {net }}$ to support the development of the system.

From this operationalization of an innovation system, the concept of energy is given by the economic value $(€)$ that is transformed according to the first principle of thermodynamics. This economic value will contain both exergy and anergy, that is, a useful part that contributes to the creation of added value, and another part that does not add value to the system. In the different activities that are carried out in an innovation system (see Edquist, 2011), entropy will be generated (i.e., exergy will be destroyed), what implies that expenses or costs that do not add value will emerge as sources of inefficiency. If we are to study the performance of innovation systems from an entropic point of view, it would thus be necessary to know in detail each and every process in those systems, in order to be able to assess which of these contribute with more value and which destroy more exergy. Identifying those sources of inefficiency would in turn allow for the definition of public interventions in the system to improve its overall performance.

Innovation systems are complex entities, and despite some conceptualizations have been made on the activities and functions that are carried in them (Galli and Teubal, 1997; McKelvey, 1997; Johnson, 2001; Hekkert et al., 2007) we are still far from reaching a comprehensive understanding of their behavior and the evolutionary dynamics produced in them (Edquist, 2011). As a consequence, despite some of the functions or activities of innovation systems are known and measured to date, others remain unexplored and thereby, we lack concrete indicators to characterize them. This justifies the decision made by several scholars in the literature, and also followed by ourselves in this paper, who approach the measurement of the system as a whole, rather than attempting to measure all the activities that may characterize such a system. 
The thermoeconomic literature discussed in the section 2 has identified some similarities between Temperature (T), Heat (Q) and Work (W) and their corresponding economic variables. However, the lack of studies providing an overall framework for the case of innovation systems leads us to propose a relationship between a set of $R \& D$ variables that can be deemed instrumental to characterize innovation systems, and the thermodynamic variables required by the heat pump approach followed here. Table 2 introduces the variables that are used to characterize the regional innovation systems in Mexico. These variables, as presented in section 2, have been for long used by scholars in the innovation studies literature. Two different alternatives are presented. In the former we consider the total income of Mexican firms as the main variable representing $\mathrm{QH}$, while in the latter $\mathrm{QH}$ is represented only by the income derived from R\&D investments made by firms. In both all variables are measured in monetary terms $(€)$.

Table 2.-

Indicators considered.

\begin{tabular}{lll}
\hline Variables & \multicolumn{2}{c}{ Concepts (all measured in $€$ ) } \\
& \multicolumn{1}{c}{ Alternative 1 } & \multicolumn{1}{c}{ Alternative 2 } \\
\hline$Q_{\mathrm{H}}$ & Firms' total income & Firms' income from R\&D activities \\
\hline \multirow{3}{*}{$W_{\text {net }}$} & $\begin{array}{l}\text { Annual resources employed in R\&D } \\
\text { Total business expenditure on R\&D } \\
\text { R\&D subsidies obtained in public calls } \\
Q_{\mathrm{L}}\end{array}$ & $\begin{array}{l}\text { Annual resources employed in R\&D } \\
\text { Total business expenditure on R\&D } \\
\text { R\&D subsidies obtained in public } \\
\text { calls }- \text { CONACYT calls }\end{array}$ \\
\hline COP & Firms' sales $\left(Q_{\mathrm{H}}-W_{\text {net }}\right)$ & Firms' sales $\left(Q_{\mathrm{H}}-W_{\text {net }}\right)$ \\
\hline
\end{tabular}

Source: own elaboration

We acknowledge that R\&D activities are only one of the many determinants of innovation activities, and hence, further research could aim to complement the original approach introduced in the paper by introducing additional indicators that can be representative of the behavior of the system as a whole.

\subsection{Contextualization of the case study}

Mexico is one of the largest emerging countries. It has also attempted to promote innovation as a means to improve its competitiveness. Ambitious innovation policies have been adopted in the country, to facilitate knowledge creation and its diffusion, foster technological development and its transfer to the productive subsystem, and improve the overall conditions in which the national innovation system operates (Capdevielle and Dutrénit 2012).

The Mexican economy is mainly dependent on foreign capital and to a large extent based on the maquiladora effect (Treviño, 1989). Maquiladoras are key for production in cities along the border zone between Mexico and the USA, which count with low levels of automatization and technological development, and are therefore based on traditional manual manufacturing sectors.

The low competitiveness shown by Mexico in most innovation scoreboards leads us to expect that its national innovation system may be focused on the capital city, Ciudad de Mexico, as the main metropolitan region where innovation and R\&D activities tend to concentrate, as it is the case in most centralized economies. The second potential focus of R\&D and innovation activities are those states located in the North, due to the frontier effect with the USA and the potential for benefitting from the externalities of large North-American firms with larger technological capabilities. The federal aggregated level data provided by the ESIDET survey confirms the previous hypothesis. In fact, it can be observed how the state with the apparently largest number of innovative firms, and hence with the largest potential to develop R\&D activities, is Distrito Federal (20.4\% of Mexican firms), where the capital city is located. To a large distance we find Nuevo León (7.05 \%), Jalisco (7.12 \%) and Mexico $(7.39 \%)$. 
Figure 2.-

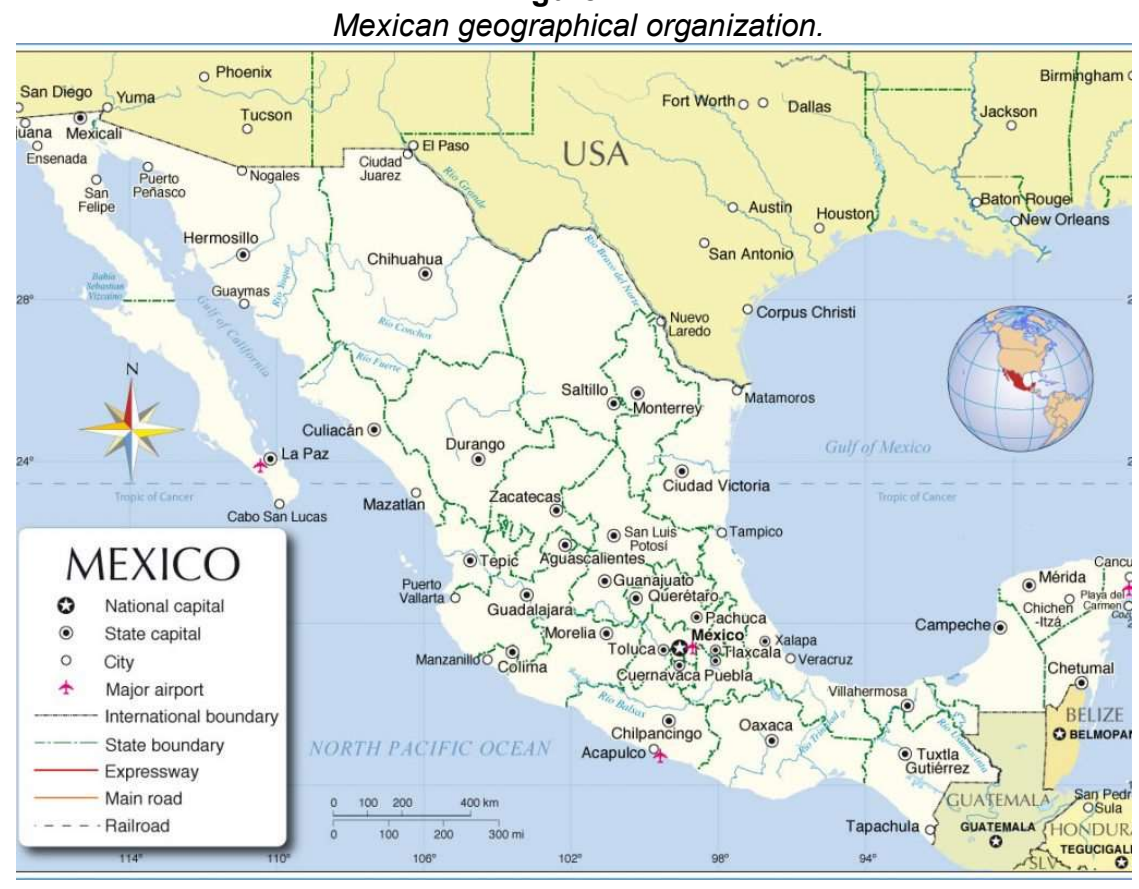

Source: Worldmaps (2018).

In order to test the heat pump approach proposed in the previous section, we resort to the data included in the ESIDET survey, which captures the values, in $€$, of variables that have been thoroughly used in the R\&D literature (see Table 2). The data has been gathered for the period 2010-2013, so we can analyze not only the R\&D performance of Mexican states, but also their evolution. The next section presents the main results of the heat pump approach applied to the Mexican states.

\section{RESULTS}

Based on the two proposals suggested in table 2, we have measured the efficiency levels achieved by all 32 Mexican states, in terms of their COP, for years 2010, 2011, 2012 and 2013. As a comparative measure, we also provide the GDP per capita for each Mexican state for year 2010, so we can have a generally accepted measure of economic performance to see the relationship between innovation performance and overall economic development.

Our results reveal how some states experience, in both models, a significant change in their $C O P$ values over the years, such as Guerrero in 2013, Campeche in 2012, or Tabasco and Zacatecas in years 2012 and 2013 (see Figure 3). The increase or decrease in the overall COP values that some states experience at particular moments in time is explained by the alterations in the number of sampled firms in each state for these particular years, and not by biases introduced by the heat pump model.

As discussed in section 3, we have developed two alternative models for measuring the COP of Mexican states in relation to innovation. The first one considers firm's total income as representative of the $\mathrm{Q}_{\mathrm{H}}$ variable, while in the second case $\mathrm{Q}_{\mathrm{H}}$ is measured by firm's income from R\&D activities. The robustness in the results achieved with both models is evidenced by the strong and positive correlation among them. As it can be observed in Figure 4, the correlation among the results with both models for years 2010, 2011, 2012 and 2013 is close to 1. Hence, despite the sampled firms in each state may significantly change from one year to another, and this leads to alterations in the values of their $C O P$, the conclusions that are achieved on the relative performance of each territory remains robust and stable over time. 
Table 3.-

Distribution of innovative firms around federal states in Mexico.

\begin{tabular}{|c|c|c|}
\hline & $\begin{array}{c}\text { United States of Mexico (by } \\
\text { alphabetical order) }\end{array}$ & $\mathrm{N}^{\mathrm{o}}$ of innovative firms \\
\hline 1 & Aguascalientes & $1.11 \%$ \\
\hline 2 & Baja California & $3.50 \%$ \\
\hline 3 & Baja California Sur & $0.73 \%$ \\
\hline 4 & Campeche & $0.61 \%$ \\
\hline 5 & Coahuila de Zaragoza & $3.61 \%$ \\
\hline 6 & Colima & $0.62 \%$ \\
\hline 7 & Chiapas & $1.36 \%$ \\
\hline 8 & Chihuahua & $3.34 \%$ \\
\hline 9 & Distrito Federal & $20.44 \%$ \\
\hline 10 & Durango & $0.94 \%$ \\
\hline 11 & Guanajuato & $5.21 \%$ \\
\hline 12 & Guerrero & $1.98 \%$ \\
\hline 13 & Hidalgo & $1.89 \%$ \\
\hline 14 & Jalisco & $7.12 \%$ \\
\hline 15 & México & $7.39 \%$ \\
\hline 16 & Michoacán de Ocampo & $1.79 \%$ \\
\hline 17 & Morelos & $1.85 \%$ \\
\hline 18 & Nayarit & $0.57 \%$ \\
\hline 19 & Nuevo León & $7.05 \%$ \\
\hline 20 & Oaxaca & $0.91 \%$ \\
\hline 21 & Puebla & $3.98 \%$ \\
\hline 22 & Querétaro & $3.71 \%$ \\
\hline 23 & Quintana Roo & $2.40 \%$ \\
\hline 24 & San Luis Potosí & $1.68 \%$ \\
\hline 25 & Sinaloa & $3.21 \%$ \\
\hline 26 & Sonora & $3.07 \%$ \\
\hline 27 & Tabasco & $1.01 \%$ \\
\hline 28 & Tamaulipas & $2.51 \%$ \\
\hline 29 & Tlaxcala & $0.42 \%$ \\
\hline 30 & Veracruz de Ignacio de la Llave & $3.02 \%$ \\
\hline 31 & Yucatán & $2.48 \%$ \\
\hline \multirow[t]{2}{*}{32} & Zacatecas & $0.48 \%$ \\
\hline & TOTAL & $100 \%$ \\
\hline
\end{tabular}

Source: own elaboration based on ESIDET data.

The rankings derived from this COP help assess the relative performance of the Mexican states and their evolution over time. According to the first model for measuring the $C O P$, the states with best performance results in year 2010 are Guerrero, Durango and Campeche, in year 2011 Quintana Roo, Guerrero and Durango, in 2012 Campeche, Guerrero and Zacatecas, and in 2013 Guerrero, Tabasco and Zacatecas. On the contrary situation, the states with the worst performance are Baja California Sur, Chihuaua and Nayarit (year 2010), Baja California Sur, Yucatán and Coahuila de Zaragoza (year 2011), Chihuaua, Querétaro and Morelos (year 2012), and Querétaro, Hidalgo and Oaxaca (year 2013). These same results are also obtained when the second model for measuring the COP is used. Without any doubt, the most intriguing result provided by this methodology is that the relative performance of the capital city, Distrito Federal, is shown to be much lower than what previous evidence may suggest. Its best performance is observed in year 2010, when it ranks 20th (out of 32 Mexican states), and the worst performance is detected in year 2012 when it ranks in 29th position.

It should be noted that the results obtained with the second model exhibit lower $C O P$ values as compared to the first model. These results are justified by the composition of the $C O P$ index in each model, since a higher numerator in the first model will also turn into a higher result of the COP index. 
As discussed in section 2, the most common approach for measuring efficiency is Data Envelopment Analysis. Valdez Lafarga and León Balderrama (2015) have applied this methodology at the level of Mexican states for year 2010 (see column 18 in Table 4 below). In order to compare our results with those by Valdez Lafarga and León Balderrama (2015), and hence, test the validity of the methodology developed in this paper, we also provide a ranking of all Mexican states, based on their COP values. Note that the COP values and the efficiency values obtained with the application of Data Envelopment Analysis are not directly comparable among themselves, thereby the need to draw upon the rankings derived from these two complementary approaches.

Figure 5 provides a graphical illustration of the correlations among the rankings obtained with the application of the COP index for years 2010, 2011, 2012 and 2013, and the results of the Data Envelopment Analysis carried out by Valdez Lafarga and León Balderrama for year 2010. In line with Zabala-Iturriagagoitia et al. (2007a) and Edquist et al. (2018) among others, our results evidence that when different methodologies are used to assess the performance of homogeneous units, the conclusions achieved with each methodology are not positively correlated. As evidenced in Figure 5, when the rankings obtained with the COP index are compared with the rankings of the Data Envelopment Analysis by Valdez Lafarga and León Balderrama there is no correlation between the two. This indicates that each methodology corresponds to a different underlying logic. From our point of view, the comprehensive assessment of the performance of an innovation system will not be attained when the community of scholars in innovation studies clarifies the different activities and functions that may lead to a full understanding of the systems' behavior. Since systems are continuously evolving, we consider this goal will not be achieved, as new activities will have to emerge in order to face the challenges of each system. In turn, we believe that combining the conclusions obtained by applying different methods can enrich the interpretations that can be made of the performance of a particular unit, let that be, a national innovation system or a company.

Figure 3.- Coefficient of Performance of Mexican states (2010-2013).

Figure 3.1.-

COP Model 1.

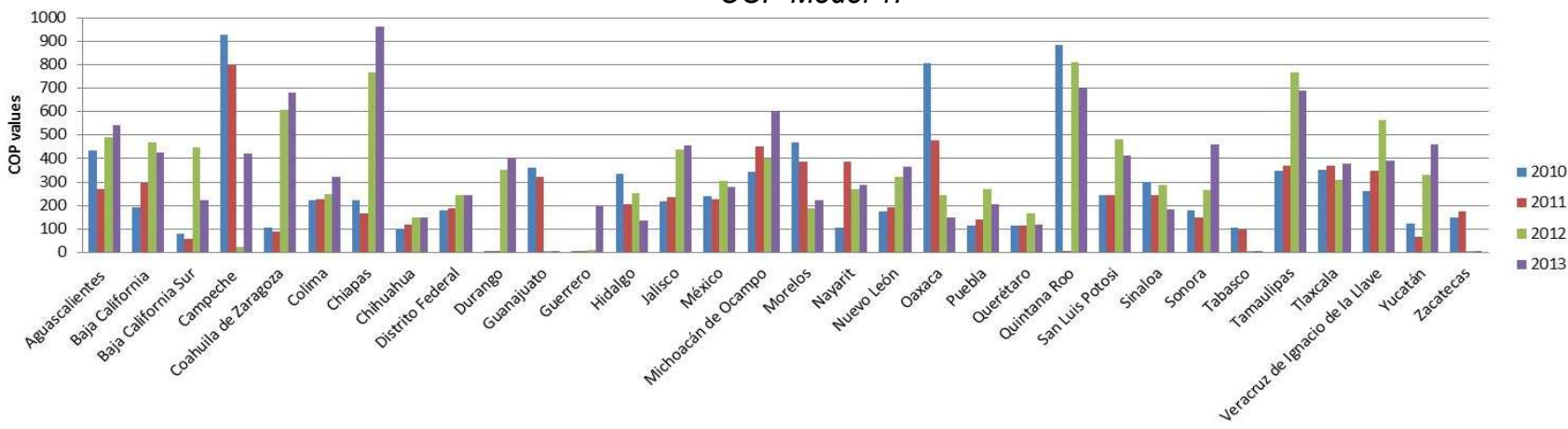

Figure 3.2.-

COP Model 2.

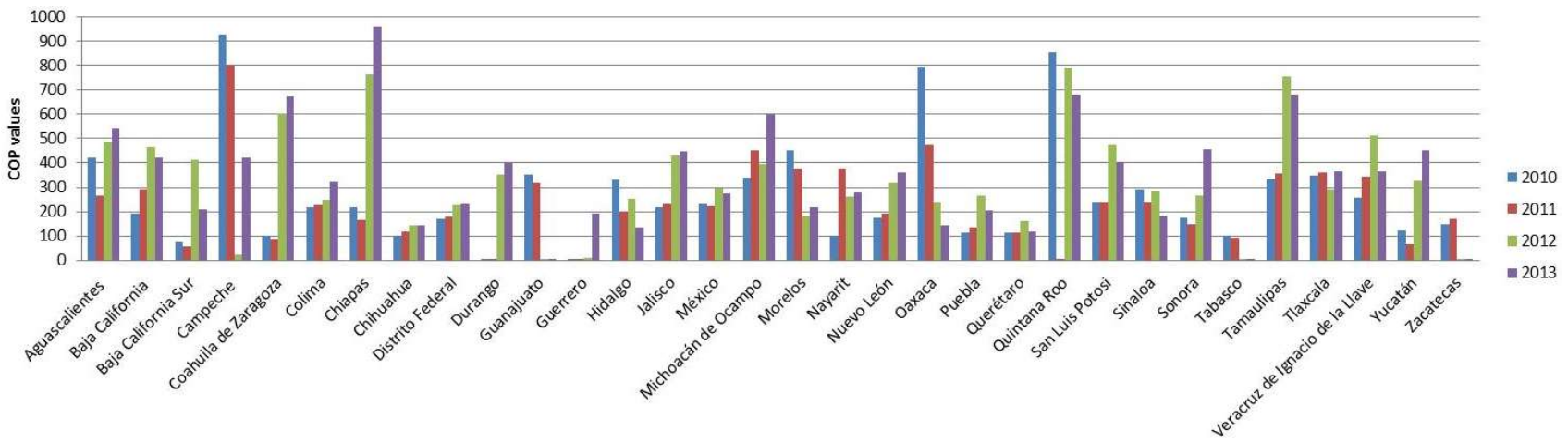


Figure 4.- Correlations among the Coefficients of Performance (2010-2013).

Figure 4.1.- Year 2010.

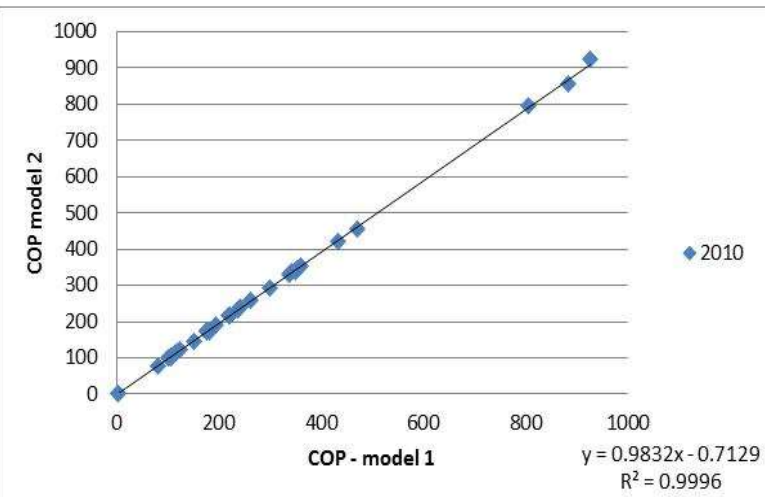

Figure 4.3.- Year 2012.

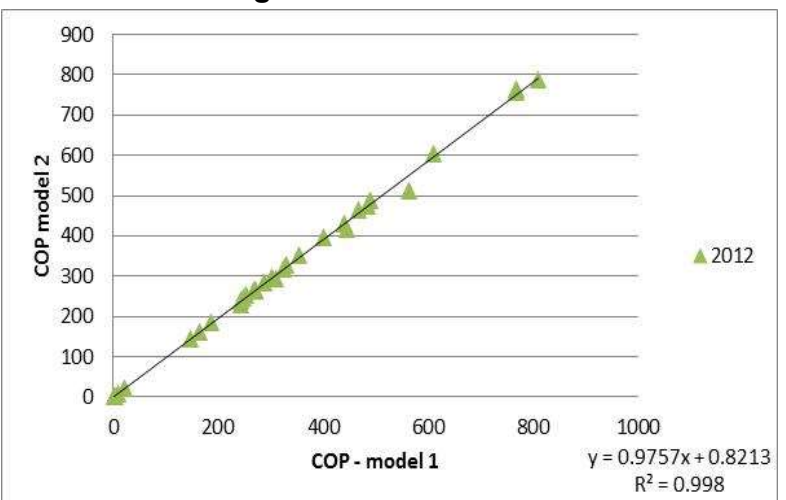

Figure 4.2.- Year 2011.

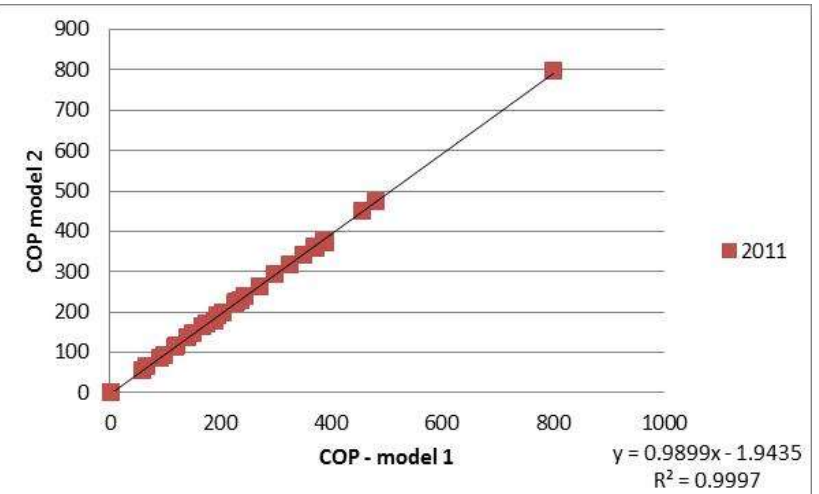

Figure 4.4.- Year 2013.

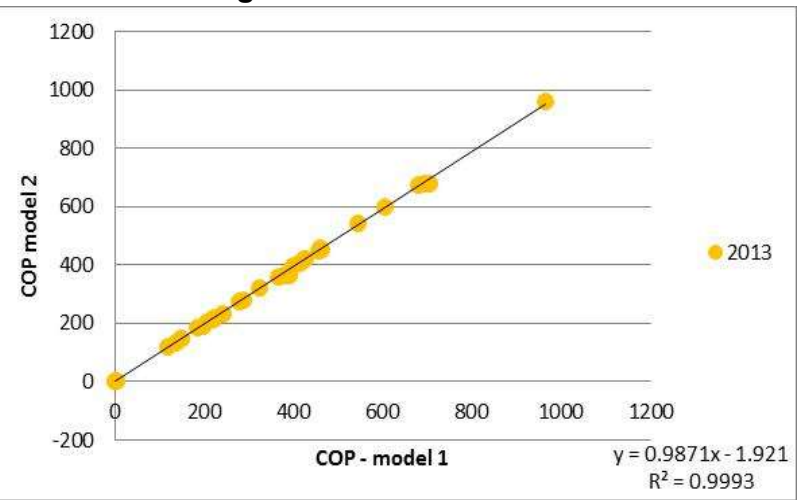

Figure 5.- Correlations among the rankings of the Coefficient of Performance and the rankings of Data Envelopment Analysis (2010-2013).

Figure 5.1.- Year 2010.

Figure 5.2.- Year 2011.

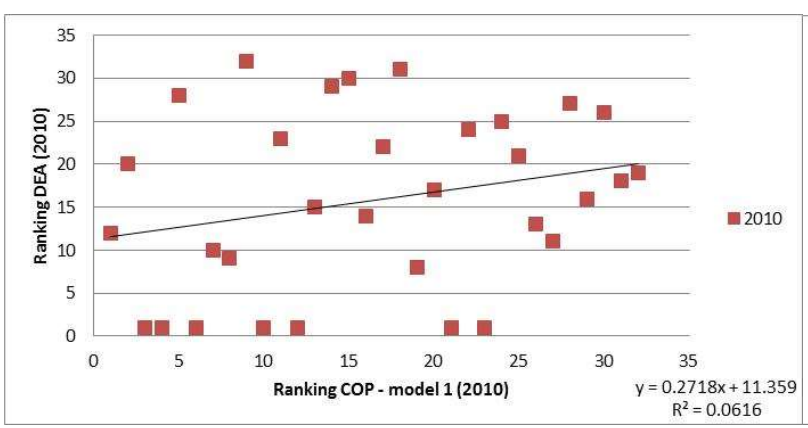

Figure 5.3.- Year 2012.

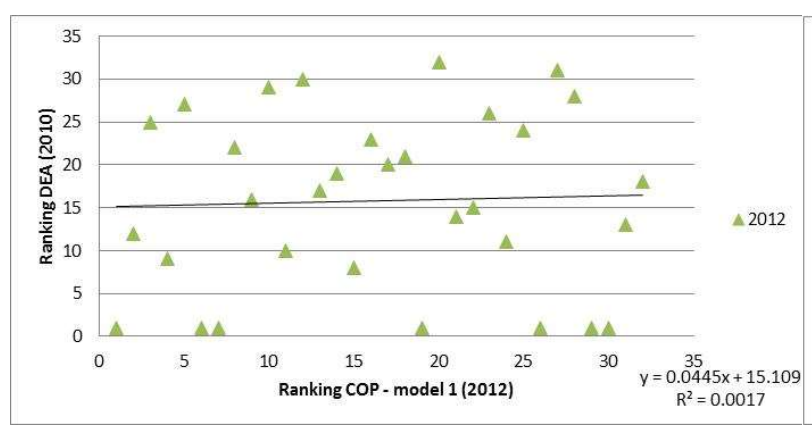

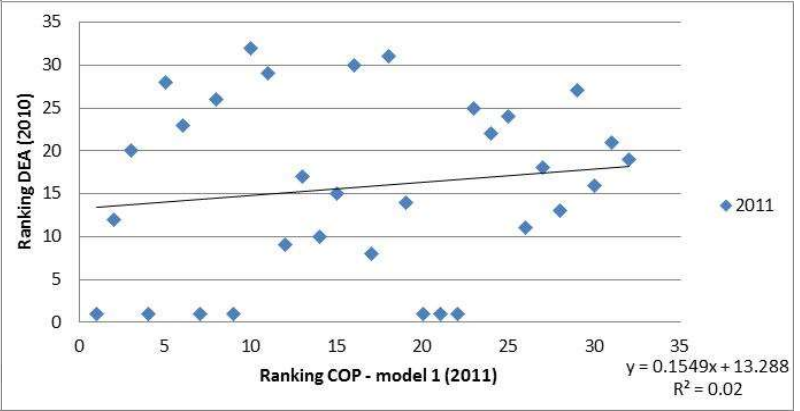

Figure 5.4.- Year 2013.

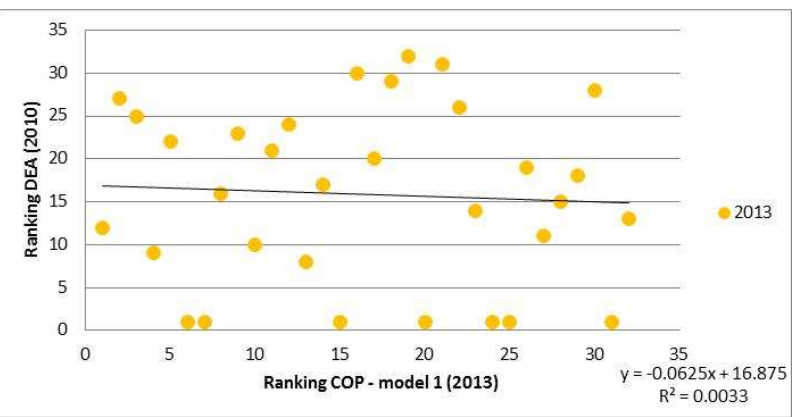


THE VALUE PUMP: INTRODUCING A THERMODYNAMIC MODEL TO ASSESS INNOVATION SYSTEMS'PERFORMANCE 75

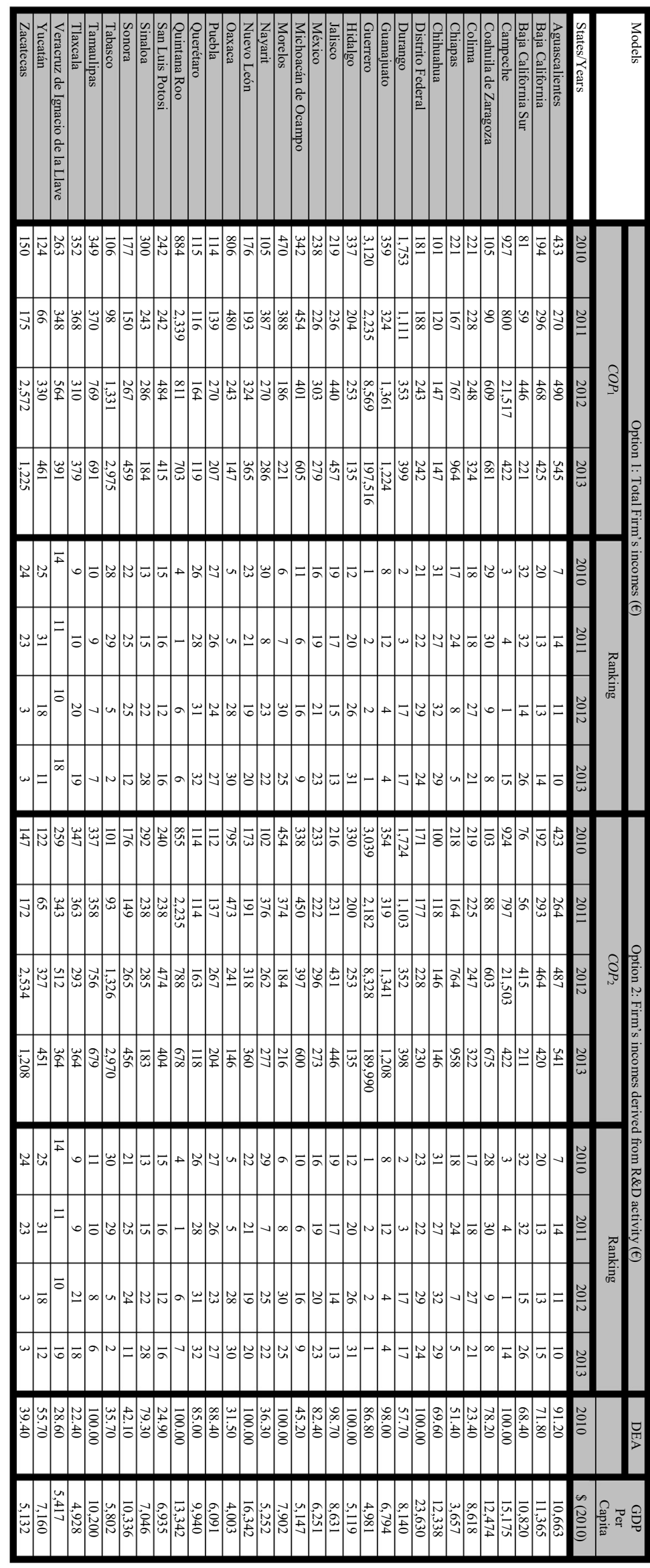

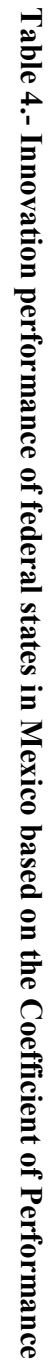


In order to contribute to the literature with another methodology to assess innovation performance, Porto-Gomez et al. (2019) have applied the methodology developed by Leydesdorff (2003), relying on information theory, and in particular on the concept of Shannon entropy. It analyses the mutual information that flows in the relations between Universities-Industries-Government, also known as the triple helix (Etzkowitz and Leydesdorff, 1995). This Shannon entropy index is representative of the synergies that are being produced at the innovation systems' level, which are defined as those interactions that favor the entrepreneurial climate for innovation.

Figure 6 includes the geographical representation of Mexican states, from four different perspectives. Figure 6.1 represents the rankings (in a scale of 1 to 32) achieved through the application of the $C O P$ index for year 2010. Figure 6.2 uses the data provided by Valdez Lafarga and León Balderrama (2015) in their Data Envelopment Analysis for year 2010 (in a scale of 0 to 100). Figure 6.3 plots the results by Porto et al. (2019) as regards the Triple Helix approach discussed above (in a scale of 0 to 30), and finally shows the rankings based on the GDP per capita of Mexican states for year 2010 (in a scale of 0 to 25,000 US\$).

As we have discussed earlier (see Figure 5), the underlying logics behind Figures 6.1 and 6.2 are different, and hence the conclusions on the relative performance on each state may also differ. While Figures 6.1 and 6.2 point to a larger heterogeneity of profiles in Mexican states however, Figures 6.3 and 6.4 evidence a more homogeneous outline. However, all four approaches seem to suggest that the best performance is detected in the federal states located in the north and south east.

\section{CONCLUSIONS}

The application of thermodynamic processes to explain economic phenomena is gaining momentum. Nonetheless, and in spite of its potential to explain technical change and firm as well as territorial dynamics, the field of innovation studies has not been approached from such thermodynamic logic. This paper has aimed to address this gap by introducing a thermodynamic approach that relies on heat pump models and that is applied to measure innovation performance at the systems level.

The approach developed in the paper is tested at the regional level in the United States of Mexico for years 2010, 2011, 2012 and 2013. The main reason why Mexico is used as a case study to question the validity and potential of the model developed in the paper is due to the unique dataset - ESIDET provided by the INEGI (National Institute of Statistics and Geography of Mexico). The thermodynamic model developed in the paper requires using variables defined in monetary terms, and the indicators included in the ESIDET survey meet this requisite.

The thermodynamic approach followed in the paper introduces the concept of 'Coefficient of Performance' $(C O P)$, which helps assess the level of performance or efficiency of an innovation system. This $C O P$ is calculated in two different models. One of them considers the total income of Mexican firms as the main variable representing $\mathrm{Q}_{\mathrm{H}}$, while the second uses the income derived from $\mathrm{R} \& \mathrm{D}$ investments made by firms as representative of $\mathrm{Q}_{\mathrm{H}}$.

Our results reveal that the conclusions achieved with the application of these two models for measuring the $C O P$ of Mexican states in relation to innovation are robust and stable over time. This $C O P$ is also compared with other approaches found in the literature for measuring innovation performance, such as Data Envelopment Analysis and the Triple Helix approach. When these different methodologies are used to assess the performance of homogeneous units however, their results are not correlated, what points to the existence of different underlying logics behind each methodology, despite the concepts used by each may be equivalent. Given these differences in the results, from our point of view, the only way in which a comprehensive understanding of the performance of an innovation system may be gained is by using as many complementary perspectives as possible. Let us introduce a metaphor to illustrate this point.

With the recent introduction of the VAR system (Video Assistant Referees), according to which referees can check those situations where they cannot have a comprehensive judgement based on their observation, referees gained a more holistic understanding of what takes place in a football game. 
THE VALUE PUMP: INTRODUCING A THERMODYNAMIC MODEL TO ASSESS INNOVATION SYSTEMS’ PERFORMANCE 77

Figure 6.- Innovation performance in Mexican states from multiple perspectives.

Figure 6.1.- Ranking based on the COP index (2010)

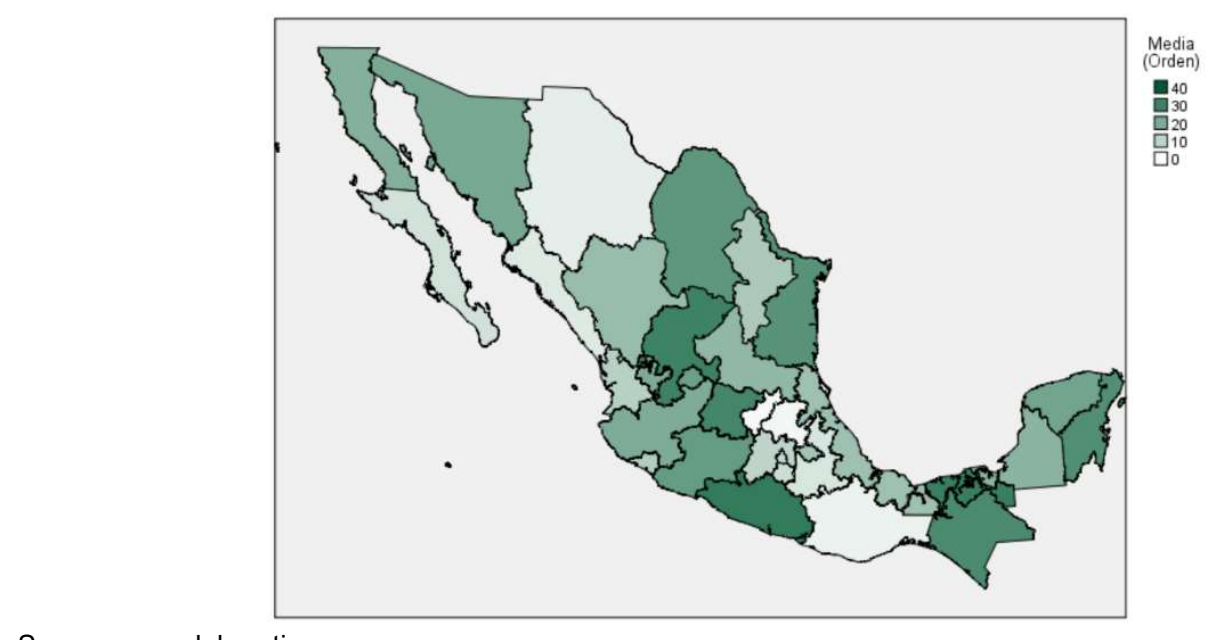

Source: own elaboration

Figure 6.2.- Efficiency levels of Data Envelopment Analysis (2010).

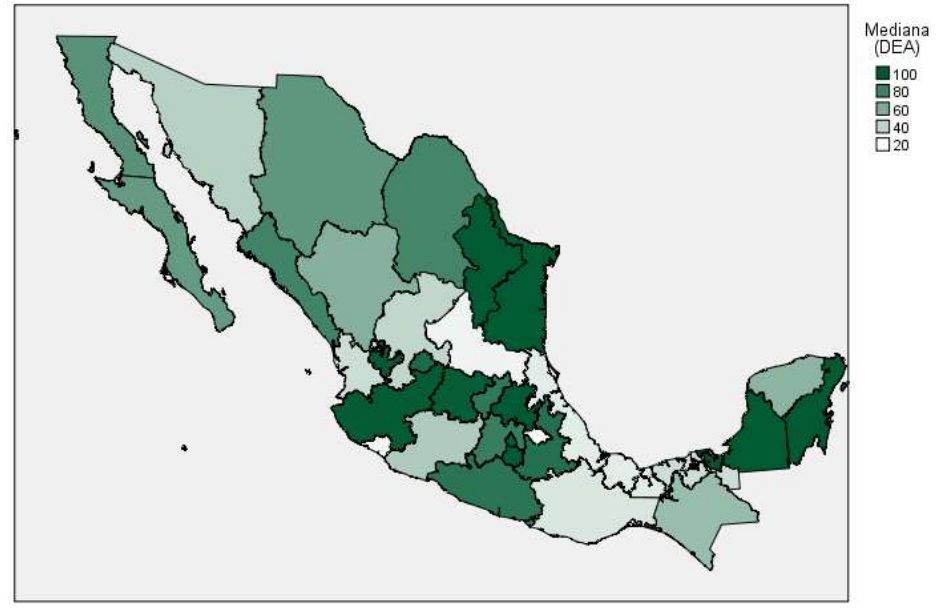

Source: own elaboration based on Valdez Lafarga and León Balderrama (2015).

Figure 6.3.- Synergy levels in the Triple Helix (2018)

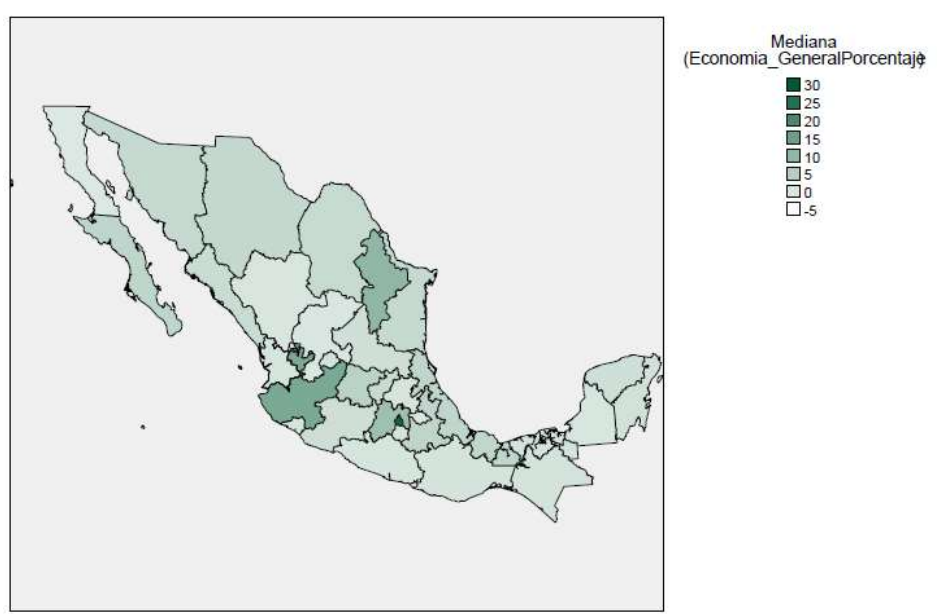

Source: Porto-Gomez et al. (2019). 
Figure 6.4.- GDP per capita (2010)

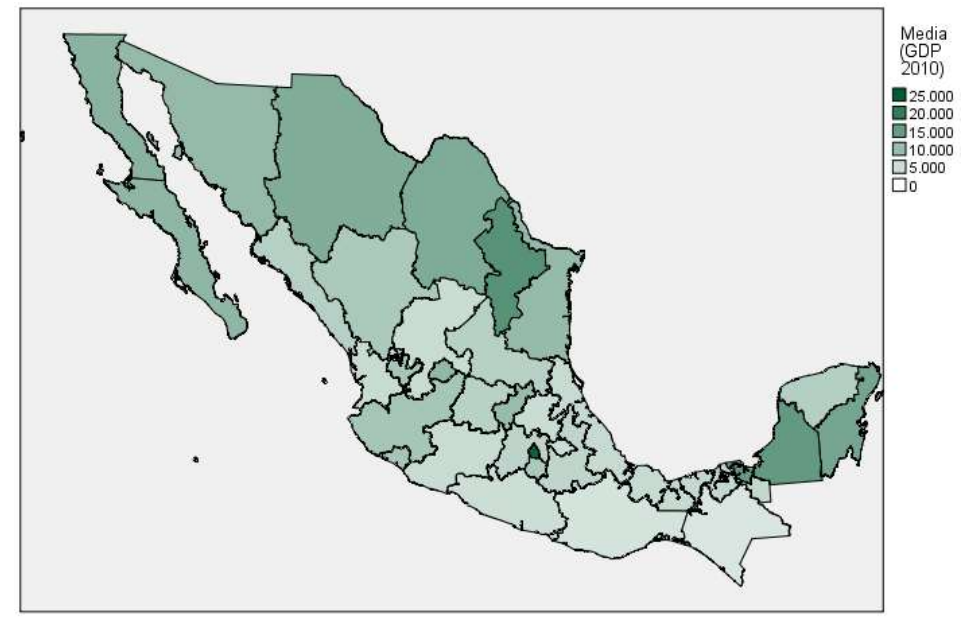

Source: own elaboration

When we say that as scholars we should aim at using as many complementary perspectives as possible to assess performance, we mean that we should use as many cameras as possible to observe a football match. The results achieved with a single methodology would be equivalent to the view of the referee on the pitch. But we all know that very often the picture the ref gets of the game is biased, because he/she cannot get the full view of the game. Including many cameras on the stadium will allow the ref to complement his/her decisions with the views that can be gained from other perspectives. Similarly, using different perspectives to assess the performance of an innovation system will allow policy makers to gain a fully-fledged understanding of its characteristics and failures. Having more cameras on the game is not only of interest for the ref however, but also to the coaches of the two teams, so they can also see the game from a different perspective.

Since the approach developed in the paper constitutes a very preliminary stage toward the development of a comprehensive thermodynamic model, we have not delved into the microdata available in the ESIDET survey, but rather rely on the aggregate data at the federal state level. Therefore, further research contributions could aim at applying this approach, or a complementary one that may be derived from it, to a context in which the scale and scope of the data included in it are able to capture the complexities of the innovation systems.

A potential area for further research may be related to the measurement of the interactions among the knowledge exploration, knowledge exploitation and the institutional subsystems. Since every innovation system needs to have all these three subsystems in place, it would be interesting to discuss which is the performance achieved by each of these subsystems independently, and then by the system as whole. As discussed in the paper though, exploring these new research paths requires gaining access to data we do not in many cases have as to date (Evangelista et al., 2002). Further research will thus also need to be developed to feed the research system with more heat that can be converted into more research work.

\section{ACKNOWLEDGEMENTS/ AGRADECIMIENTOS}

The authors are grateful to Dr. Jose Ramón Otegi for having introduced Igone Porto-Gomez and Jon Mikel Zabala-Iturriagagoitia to Dr. Cristina Gutierrez-Cañas Mateo. Her accessibility, availability and commitment were essential in the early stages of this endeavor. The authors would also like to thank Sergio Gutierrez Castro, who accepted the proposal to work with us in his Master's degree. Finally, we would also like to thank Dr. Natalia Volkow and the National Institute of Statistics and Geography of Mexico (INEGI) for grating us access to the ESIDET data (LM 874-2018) and to Jose Ricardo Lopez Robles for his comments on an earlier draft. Igone Porto-Gomez and Jon Mikel Zabala-Iturriagagoitia acknowledge financial support from the Basque Government Department of Education, Language Policy and Culture (IT 885-16). 


\section{REFERENCIAS BIBLIOGRÁFICAS}

ABBASSI, M., ASHRAFI, M., TASHNIZI, E.S. (2014) Selecting balanced portfolios of R\&D projects with interdependencies: A Cross-Entropy based methodology. Technovation, 34(1), 54-63.

AUDRETSCH, D. B., Feldman, M.P. (1996) R\&D spillovers and the geography of innovation and production. The American economic review, 86(3), 630-640.

AUTIO, E. (1998) Evaluation of RTD in Regional Systems of Innovation. European Planning Studies, 6(2), 131140.

BALI, S. (2011) Econophysics, thermoeconomics and finance. Journal of International Social Research, 4(18), 379388.

BORRAS, S., EDQUIST, C. (2019) Holistic Innovation Policy: Theoretical Foundations, Policy Problems and Instrument Choices. Oxford University Press, Oxford.

BRACZYKH. J., COOKE P., HEIDENREICH, M. (EDS) (1998) Regional Innovation Systems. UCL Press, London.

CAI, Y., LIU, C. (2014) The roles of universities in fostering knowledge-intensive clusters in Chinese regional innovation systems. Science and Public Policy, 42(1), 15-29.

CAPDEVIELLE, M., DUTRÉNIT, G. (2012) Políticas para el desarrollo productivo y la innovación: desafío y oportunidad para la economía mexicana. Nueva estrategia de industrialización, 153-185.

CARAYANNIS, E., GRIGOROUDIS, E. (2014) Linking innovation, productivity, and competitiveness: implications for policy and practice. Journal of Technology Transfer, 39, 199-218.

CARLSSON, B., JACOBSSON, S. (1994) Technological systems and economic policy: the diffusion of factory automation in Sweden. Research Policy, 23, 235-248.

CHARNES, A., COOPER, W.W., RHODES, E. (1978) Measuring the efficiency of decision-making units. European Journal of Operational Research, 2(6), 429-444.

CHEN, K., GUAN, J. (2012) Measuring the Efficiency of China's Regional Innovation Systems: Application of Network Data Envelopment Analysis (DEA). Regional Studies, 46(3), 355-377.

CLEVELAND, C. (2006) Dictionary of Energy, Amsterdam: Elservier. In: Wissler, J. (2006). Achieving Balance, Air and Space Power Journal, Vol. 23 (4), 25-35.

COOKE, P., URANGA, M. G., ETXEBARRIA, G. (1997) Regional innovation systems: Institutional and organisational dimensions. Research Policy, 26(4-5), 475-491.

DOLOREUX, D., PORTO-GOMEZ, I. (2017) A review of (almost) 20 years of regional innovation systems research. European Planning Studies, 25(3), 371-387.

EDQUIST, C. (Ed.) (1997) Systems of Innovation: Technologies, Institutions and Organizations. Pinter, London.

EDQUIST, C. (2011) Design of innovation policy through diagnostic analysis: identification of systemic problems (or failures). Industrial and Corporate Change, 20(6), 1725-1753.

EDQUIST, C., ZABALA-ITURRIAGAGOITIA, J.M., BARBERO, J., ZOFÍO, J.L. (2018) On the meaning of innovation performance: Is the synthetic indicator of the Innovation Union Scoreboard flawed?. Research Evaluation, 27(3), 196-211.

ETZKOWITZ, H., LEYDESDORFF, L. (1995) The triple helix-university-industry-government relations: A laboratory for knowledge-based economic development. EASST Review, 14, 14-19.

EVANGELISTA, R., IAMMARINO, S., MASTROSTEFANO, V., SILVANI, A. (2001) Measuring the regional dimension of innovation. Lessons from the Italian Innovation Survey. Technovation, 21(11), 733-745.

EUROPEAN COMMISSION (2011) Regional Policy for Smart Growth in Europe 2020. European Commission, Brussels.

EUROPEAN COMMISSION (2012) Guide to Research and Innovation Strategies for Smart Specialisation (RIS 3). European Commission, Brussels.

FAGERBERG, J., FOSAAS, M., SAPPRASERT, K. (2012) Innovation: Exploring the knowledge base. Research Policy, 41(7), 1132-1153.

FREEMAN, C. (2002) Continental, national and sub-national innovation systems-complementarity and economic growth. Research Policy, 31(2), 191-211.

GALLI, R., TEUBAL, M. (1997) Paradigmatic shifts in national innovation systems. In Edquist, C. (Ed.) Systems of Innovation: Growth, Competitiveness and Employment. Pinter, London, pp. 342-364.

GEORGESCU-ROEGEN, N. (1976) The Entropy Law and the Economic Process. 3. vyd. Cambridge, London : Harvard University Press. xv, 457 s. ISBN 0-674-25781-2.

GÓMEZ-URANGA, M., ETXEBARRIA, G. (2015) Thermodynamic Properties in the Evolution of Firms and Innovation Systems. Available: HTTPS://PAPERS.SSRN.COM/ SOL3/PAPERS.CFM?ABSTRACT_I $\mathrm{D}=2697747$.

GRUPP, H. (1990) The concept of entropy in scientometric and innovation research. An indicator for institutional involvement in scientific and technological developments. Scientometrics, 18(3-4), 219-239.

HAIPING, S. (2013) An Empirical Study on Performance Evaluations of Regional Innovation System Based on Management Entropy Theory. WHICEB 2013 Proceedings, 38. Available: https://aisel.aisnet.org/whiceb2013/38.

HE, L., LIU, Y. (2015) Based on Entropy Method Regional Innovation Capability Evaluation in Gansu Province. In: Proceedings of the Ninth International Conference on Management Science and Engineering Management (pp. 893-901). Springer, Berlin, Heidelberg.

HEKKERT, M.P., SUURS, R.A.A., NEGRO, S.O., KUHLMANN, S., SMITS, R.E.H.M. (2007) Functions of innovation systems: A new approach for analyzing technological change. Technological Forecasting \& Social Change, 74, 413-432. 
HOWITT, P., AGHION, P. (1998) Capital accumulation and innovation as complementary factors in long-run growth. Journal of Economic Growth, 3(2), 111-130.

IVANOVA, I. A., LEYDESDORFF, L. (2014) Rotational symmetry and the transformation of innovation systems in a Triple Helix of university-industry-government relations. Technological Forecasting and Social Change, 86, 143-156.

JOHNSON, A. (2001) Functions in Innovation System Approaches. Paper for DRUID's Nelson-Winter Conference. 2001. Aalborg, Denmark.

LEYDESDORFF, L. (2001) Indicators of innovation in a knowledge-based economy. Science \& technology dynamics. Cybermetrics 5, paper 2.

LEYDESDORFF, L. (2003) The mutual information of university-industry-government relations: An indicator of the triple helix dynamics. Scientometrics, 58(2), 445-467.

LEYDESDORFF, L., Porto-Gomez, I. (2019) Measuring the expected synergy in Spanish regional and national systems of innovation. The Journal of Technology Transfer, (44) 189-209.

LUNDVALL, B.A. (Ed.) (1992) National Systems of Innovation. Towards a Theory of Innovation and Interactive Learning. Pinter, London.

MALERBA, F. (2002) Sectoral systems of innovation and production. Research Policy, 31(2), 247-264.

MARTIN, B. (2012) The evolution of science policy and innovation studies. Research Policy, 41(7), 1219-1239.

MCCAULEY, J.L. (2006). Response to "worrying trends in econophysics". Physica A: Statistical Mechanics and its Applications, 371(2), 601-609.

MCKELVEY, M. (1997) Using evolutionary theory to define systems of innovation. In Edquist, C. (Ed.) Systems of Innovation: Growth, Competitiveness And Employment. Pinter, London, pp. 200-222.

METCALFE, J.S. (1995) Technology systems and technology policy in an evolutionary framework. Cambridge Journal of Economics, 19, 25-46.

MOULAERT, F., SEKIA, F. (2003) Territorial innovation models: A critical survey. Regional Studies 37, $289-302$.

NARULA, R., SANTANGELO, G. D. (2009) Location, collocation and R\&D alliances in the European ICT industry. Research Policy, 38(2), 393-403.

NASIEROWSKI, W., ARCELUS, F.J. (2012) About Efficiency Of Innovations: What Can Be Learned From The Innovation Union Scoreboard Index. Procedia - Social and Behavioral Sciences, 58, 792-801.

NAUWELAERS, C., REID, A. (1995) Methodologies for the evaluation of regional innovation potential. Scientometrics, 34(3), 497-511.

NELSON, R.R. (Ed.) (1993) National Innovation Systems: A Comparative Analysis. Oxford University Press, New York.

OECD/Eurostat (2018) Oslo Manual - 2018. Guidelines for collecting and interpreting innovation data. Fourth Edition. OECD/European Commission.

PATI, S. P. (2009) Stress management and innovation: A thermodynamic view. Journal of Human Thermodynamics, (5), 22-32.

PELOROSSO, R., GOBATTONI, F., LEONE, A. (2017) The low-entropy city: A thermodynamic approach to reconnect urban systems with nature. Landscape and Urban Planning, 168, 22-30.

PLEROU, V., GOPIKRISHNAN, P., STANLEY, H.E. (2003) Econophysics: Two-phase behaviour of financial markets. Nature, 421(6919), 130.

PORTO-GOMEZ, I., OTEGI OLASO, J.R., ZABALA-ITURRIAGAGOITIA, J.M. (2016) ROSA, ROSAE, ROSIS: Modelling a regional, open, sectoral innovation system. Entrepreneurship \& Regional Development, 28(1-2), 2650 .

PORTO-GOMEZ, I., ZABALA-ITURRIAGAGOITIA, J.M., LEYDESDORFF, L. (2019) Innovation Systems in México: A Matter of Missing Synergies. Technological Forecasting and Social Change, under review.

RICHARDS, G.R. (2000) Reconciling econophysics with macroeconomic theory. Physica A: Statistical Mechanics and its Applications, 282(1-2), 325-335.

RICKLES, D. (2008) Econophysics and the complexity of the financial markets. In: J. Collier \& C. Hooker (Eds.), Handbook of the Philosophy of Science, vol. 10: Philosophy of Complex Systems, North Holland Elsevier Editions, New York.

ROSSER, J.B. (2008) Econophysics and economic complexity. Advances in Complex Systems, 11(05), 745-760.

SANTIAGO, F., DE FUENTES, C., DUTRÉNIT, G., GRAS, N. (2017) What hinders innovation performance of services and manufacturing firms in Mexico?. Economics of Innovation and New Technology, 26(3), $247-268$.

SASLOW, W.M. (1999) An economic analogy to thermodynamics. American Journal of Physics, 67(12), 1239-1247.

SCHUMPETER, J.A. (1934) The theory of economic development. Harvard University Press, Cambridge, MA.

TREVIÑO, M. (1989) Regulation of technology transfer: The Mexican experience. The Journal of Technology Transfer, 14(1), 46-51.

TRIBUS, M., EVANS, R. (1962) A Contribution to the Theory of Thermoeconomics. University of California Los Angeles (UCLA). Dept. of Engineering. Report 62-3 6. [The beginning of a concrete formulation of thermoeconomics.]

VALDEZ-LAFARGA, C., LEÓN-BALDERRAMA, J.I. (2015) Hacia una taxonomía de los sistemas regionales de innovación en México. Economía, sociedad y territorio, 15(48), 517-553.

VERSPAGEN, B. (2005) Innovation and Economic Growth. In: J. Fagerberg, D. C. Mowery, R.R. Nelson (Eds.) The Oxford Handbook of Innovation. Oxford University Press, Oxford.

WEBER, H., MAHNKE, R., KAUPUŽS, J., STRÖMBERG, A. (2007) Models for highway traffic and their connections to thermodynamics. In: Traffic and Granular Flow'05 (pp. 545-550). Springer, Berlin, Heidelberg. 
THE VALUE PUMP: INTRODUCING A THERMODYNAMIC MODEL TO ASSESS INNOVATION SYSTEMS' PERFORMANCE 81

WORLDMAPS (2018) Map of México states and capitals. Available: https://pasarelapr.com/images/map-of-mexicostates-and-capitals/map-of-mexico-states-and-capitals-1.jpg.

ZABALA-ITURRIAGAGOITIA, J.M., VOIGT, P., GUTIÉRREZ-GRACIA, A., JIMÉNEZ-SÁEZ, F. (2007a) Regional Innovation Systems: How to Assess Performance. Regional Studies, 41(5), 661-672.

ZABALA-ITURRIAGAGOITIA, J.M., JIMÉNEZ-SÁEZ, F., CASTRO-MARTíNEZ, E., GUTIÉRREZ-GRACIA, A. (2007b) What indicators do (or do not) tell us about Regional Innovation Systems. Scientometrics, 70(1), 85106.

ZAPART, C.A. (2015) Econophysics: A challenge to econometricians. Physica A: Statistical Mechanics and its Applications, 419, 318-327. 